\title{
COMMUNICATION, TEAMWORK, MOTIVATION AND RESOLUTION OF CONFLICTS IN THE NEW UNIVERSITY TEACHING METHODOLOGY
}

\author{
M.A. López-Peral, E. García-González, M.D. Andújar-Montoya \\ University of Alicante (SPAIN)
}

\begin{abstract}
In the last years of university education, especially in technical degrees, the university faculty finds a profile of students whose attitude is far from being a professional in a short space of time. The present research focuses on the role of the professor as a connector between the university and the business world of the 21st century job market which demands new skills from students, not just knowledge. Nowadays companies look for motivated people, able to resolve conflicts and work as a team ... that is, leaders who made flow communication in the company. Social skills are learned behaviours, so therefore, can be taught. Here is the importance of changing the learning model. Then, this paper focus on the importance of teaching the following disciplines: communication, leadership, teamwork, motivation and conflict resolution. These skills must be acquired during the formative years. The methodology presented here has been carried out in the subject "Construction Equipment, Installation and Auxiliary Resources" of the third year of the Degree in Technical Architecture at the University of Alicante. Traditionally, the teaching of this subject has been theoretical, with lecture classes. During the last years, as a transition, after bad academics results obtained from this perspective, its conception has completely changed, becoming a totally practical subject. Nowadays, students have the necessary didactic resources, to become the manager of their learning. This new methodology highlights the team work among the students, by searching information related to the topics previously explained. The methodology includes students as an active participant in the session where they have to expose to their classmates the results of their work, fostering leadership, motivation and selfesteem, and breaking the barrier of speak in public. With this methodology, after years of decline, academic results have improved again. Students are now motivated, and they have a greater optimization of the class time so they can easily reach the objectives marked by the subject. Another relevant improvement is their change of attitude towards their future business life. This innovative didactic approach addresses teaching in conflict resolution, where the issue is not about eliminating or preventing the conflict but to assume those situations and leave enriched of them. The present study had positive results for both teachers and students and the proposed methodology can be applied to many branches of knowledge, hence the importance of their disclosure.
\end{abstract}

Keywords: communication, teamwork, motivation, resolution of conflicts.

\section{INTRODUCTION}

The teaching methodology exposed has been adopted by professors of the degree of Technical Architecture in the University of Alicante, as a consequence of the new student profile identified in higher education. The research focuses on the need of dynamism in the subjects and classrooms where students must be an active part of the knowledge process.

Traditional teaching has been relegated to the background. Subjects had also to be adapted into the new requests.

During the last academic years in the compulsory subject " Construction Equipment, Installation and Auxiliary Resources" of third year in Technical Architecture, new activities in the classroom have been adopted in order to encourage student's participation, as well as their involvement in the learning process. Also, these activities looked for raising their self-esteem, and manage with the collaborative work in order to find the problems solutions.

These advantages of work are applicable to whatever subject, being the core issue the methodology of learning, that helps them to face their imminent jump into the professional life. 


\subsection{Specific issue of the case study}

During the last academic years it was identified that student's attendance had decreased considerably in the lecture sessions. However it was observed that the level of attendance and participation was increasing in the practical ones. In the new syllabus there are no incompatibilities between signatures as it was used to happen. This situation delimits students enrolled in subjects when they feel incapability to assimilate contents because they have not passed the preceding subjects yet.

Moreover, technical vocabulary is often not used by students, which implies that the lack of concepts understanding is not because of the difficulty of concepts but rather due to the inherent knowledge deficiencies of the student.

The subject "Construction Equipment, Installation and Auxiliary Resources" aims to provide the necessary theoretical knowledge about the most used machines in the construction sector, being our main concern, as professors, how to teach the successfully manage of the resources of a building construction. Taking advantage of the students' good attitude towards the use of new technologies, the according to the situation previously explained, the present work proposes methodological changes based on the use of new technologies in the classroom [1].

\subsection{Gamification as a model}

The new methodology is based on the principles of gamification [2]. Gamification consists on a strategy to motivate groups of people by using gaming tools in non-play environments, in order to increase motivation, concentration, effort, loyalty and other positive values [3]. This learning methodology motivates students to improve their academic performance and consequently their results. Dynamic classes are more attractive to students and therefore, they are able to achieve the desired goals [4]. We have also searched the use of ICT as well as various techniques for collaborative learning [5].

\subsection{Purpose}

The purpose of this paper is to share the results of our experience that was carried out during the first four months of the academic year 2016-2017 with the implementation of three groups of new activities: 1. Search of information of the contents of the subject, 2. Collaborative workshops with defence of the proposed themes through poster exhibitions, 3. The use of an Audience Response System (Socrative application) as a self-assessment of the student's learning in real time.

\section{METHODOLOGY}

The experience was performed in the subject of "Construction Equipment, Installation and Auxiliary Resources" of the third year of the degree of Technical Architecture, Figure 1. The new activities took place into the classroom and they were done by pairs, sharing the results obtained. Each of them is summarized in the next sections [6].

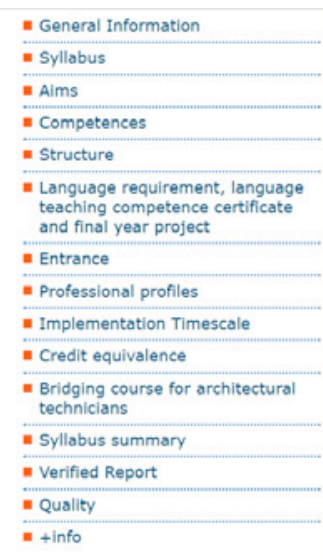

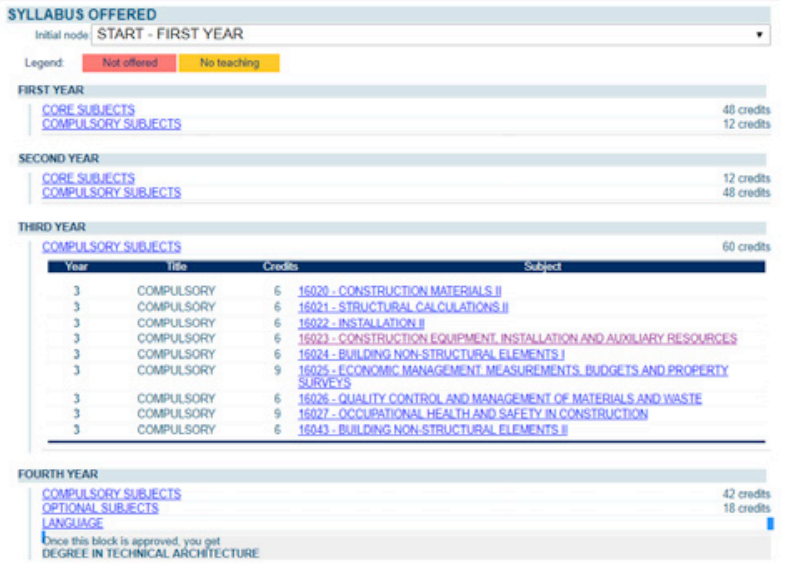

Figure 1. Syllabus.

https://cvnet.cpd.ua.es/webcvnet/planestudio/planEstudioND. aspx?plan=C206\&/engua=E\&caca=2017-18\# 


\subsection{Search of information of the subject contents}

At the beginning of the course the student had available in the virtual campus, all the theoretical information of the subject. During the academic course, the search for information on specific questions asked for each group by the teacher was proposed. The work was done in class, for this reason they had to take with them a laptop or a tablet. It was intended to guide the student in the choice of the correct information in technical and updated webs. At the end of the last session of each topic, the results were shared. This practice was included in the continuous evaluation of the subject.

The interest in the subject increased, being reflected in the high attendance of the students to the lecture classes, where they interacted with their classmates and with the teacher [7]. As an example, a type sheet, created to work in class about excavation machinery is presented in Figure 2.
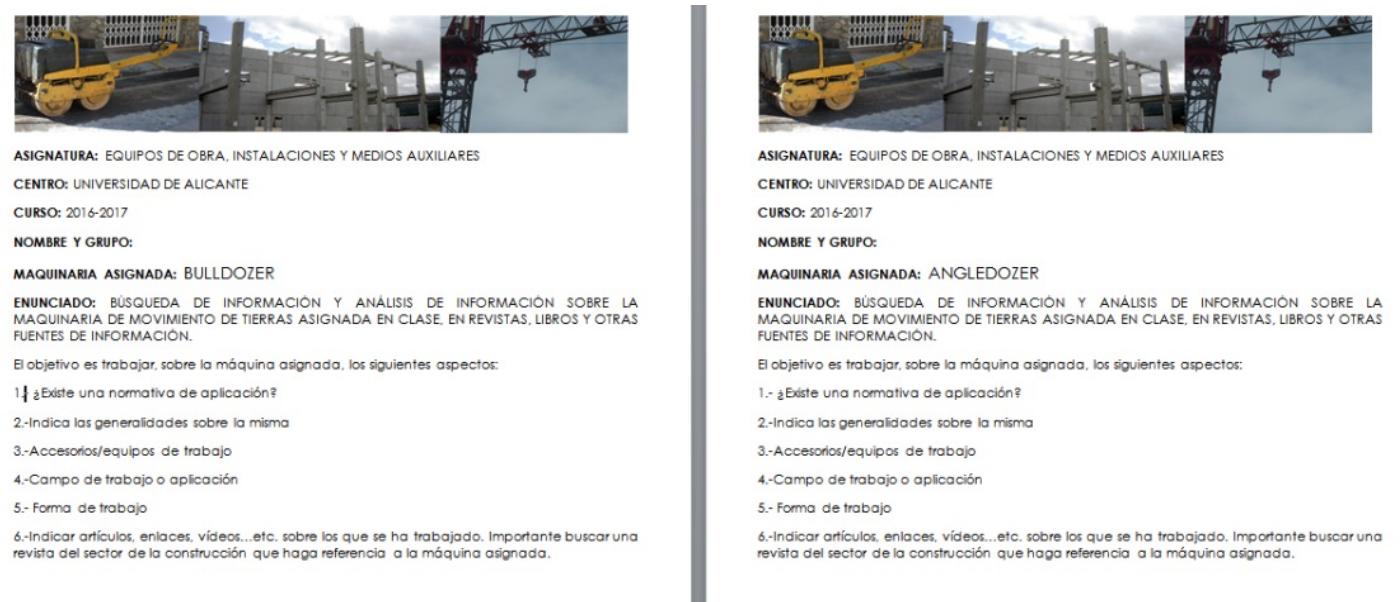

Figure 2. Search information type sheet.

\subsection{Collaborative workshops}

With the idea of a global learning, during the academic year two collaborative workshops were held with leading companies in the sector and other schools. Thus, one of the activities consisted of a conference based on the demands of the students about what are the different professional branches, specifically the figure of the Project Management Professional. A collaborative workshop was also held with students of the Emergency Management and Civil Protection Course at the Leonardo da Vinci secondary school. The workshop was about emergency shoring.

Figure 3 shows the diffusion that was made of these activities and some photographs of the workshop. Finally the students under the continuous assessment plan develop a poster and explain it to their peers.

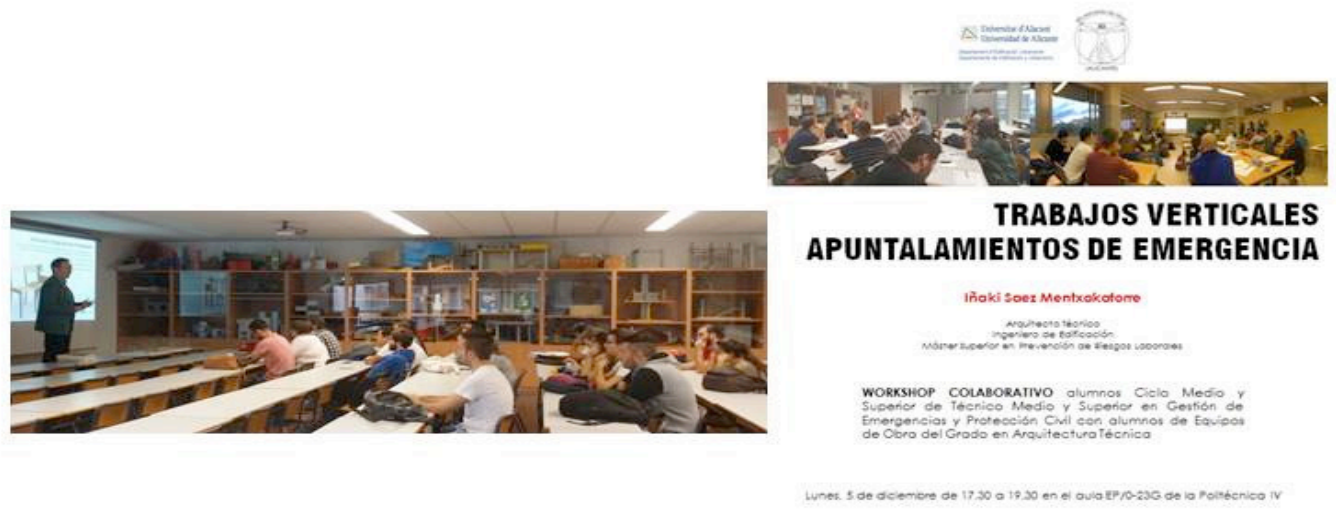

Figure 3. Collaborative workshop. 


\subsection{The use of an Audience Response System}

In order to self-evaluate the knowledge and try to avoid conventional situations of test-type tests, it was proposed to carry out a questionnaire at the end of each topic (multiple choice, true or false and short answers) through an Audience Response System. The selected tool was "Socrative" (http://www.socrative.com/) which is free and provides a platform for the student and another platform for the teacher. The professor had an identifier for each class and the student connected to the application from the classroom identifier. Depending on the modality, the student received comments on whether their answers were correct and why. Finally, the teacher could export individual responses in excel or pdf format for further detailed analysis. The application also allowed generating the questionnaire in pdf format.

The questionnaires had the purpose of a funny way self-evaluation [8]. We tried to unlink the performance to the formalism of obtaining a numerical mark. This decision was based on the intention to avoid the stress produced by activities with numerical value that would avoid the pleasant learning that was pursued. Errors were not taken into account. They were used to improve learning, reduce the inequalities of knowledge between them and make them feel less fearful of participating and give their opinion on the topic that is discussed, Figure 4.

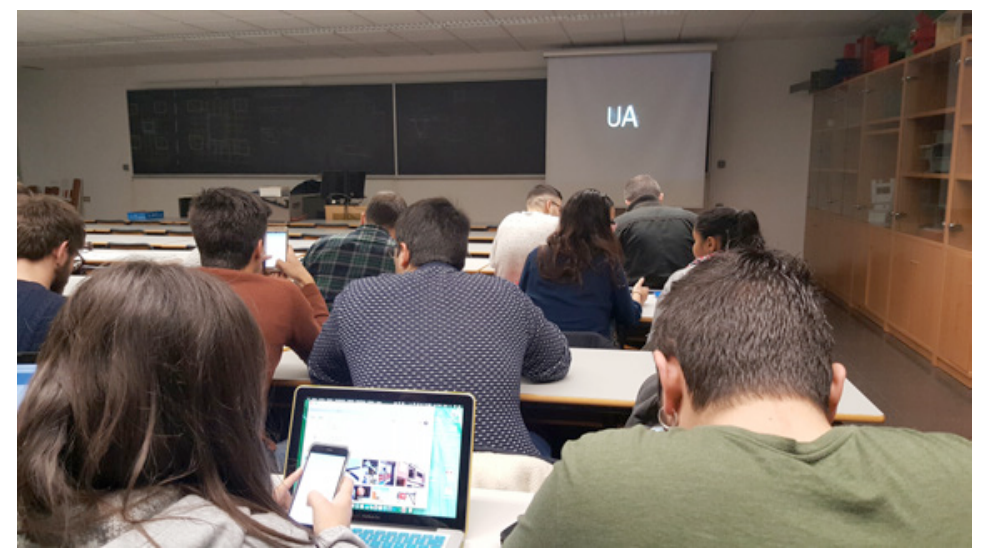

Figure 4. Questionnaires done in class with Socrative app.

The professor, who was connected to the application Socrative Teacher Version, could see the results in real time, Figure 5. After the complete resolution of the test, the teacher could re-explain the correct solutions that were incorrectly answered in a massive way and re-emphasized issues of the lectures that were not understood.

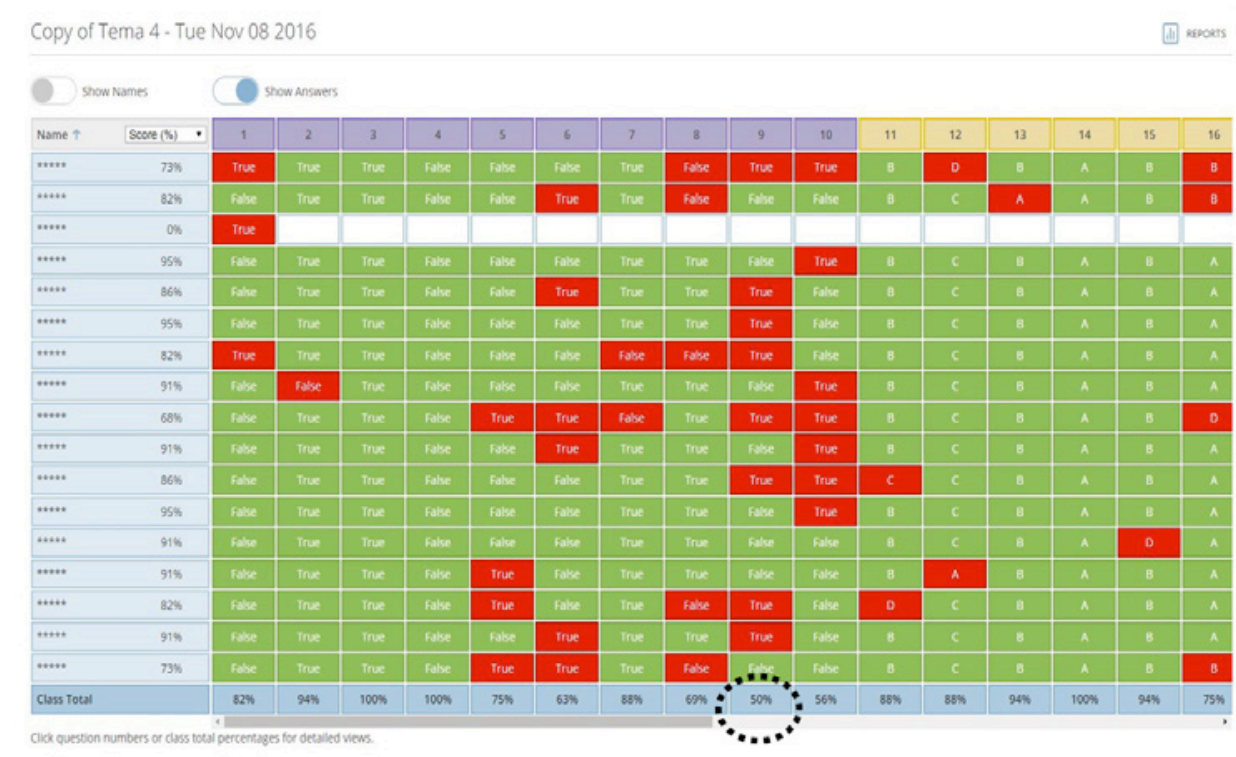

Figure 5. Socrative Teacher Version. Results in real time. 


\section{RESULTS}

In the theoretical classes was possible to visualize that students showed more interest in the subject by working with their classmates instead of attending a traditional theoretical lecture. As they got involved with the contents of the subject, they acquired more vocabulary, ability to understand the subjects and minimize the insecurity when they have to ask some doubt [9].

With the implementation of the Socrative app for the theoretical part it was denoted an improvement of academic performance, obtaining an $88 \%$ students of good marks and taking into account that there was a $10 \%$ of the students that didn't appear in any of the official calls. It should be highlighted that the results of these questionnaires were a personal self-assessment that were not taken into account for the final score of the continuous assessment, Figure 6.

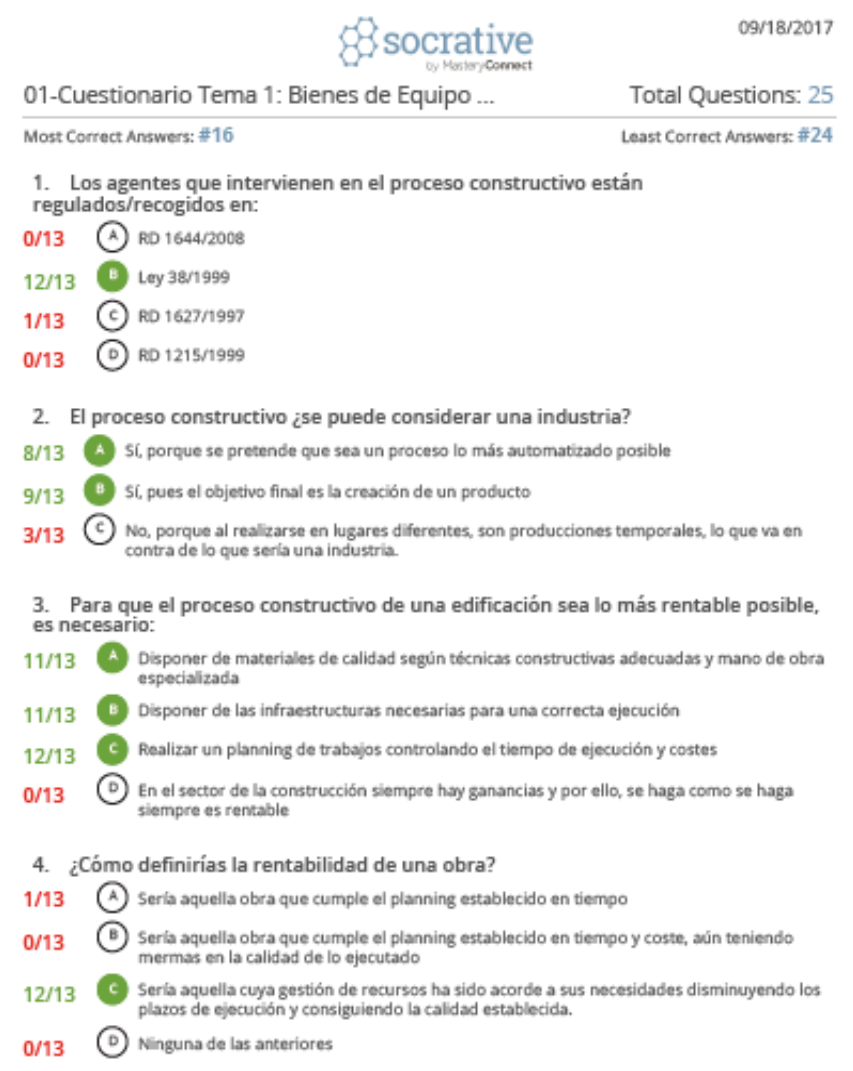

Figure 6. Socrative Quiz reports.

In order to determine the degree of student satisfaction with this new structure of theoretical classes and whether or not to eliminate the lecture class, the following questions were asked in the anonymous survey:

- Did you like the focus of the classes? Conduct questionnaires with new technologies, perform practices and search for information before explaining the theme, sharing ideas, making and exposing the posters?

- How would you like to be taught?

- Do you think the lecture should be eliminated?

The answers were similar. They agree with the most interesting has been the pooling of knowledge and they liked the approach of the classes although they consider that the subject and content of the subject is excessive.

They also agree that they would like to visit companies related to the sector.

In general, everyone has answered that they will not eliminate the lecture and agree to transform them and make them more participatory and dynamic. 


\section{CONCLUSIONS}

The purpose of the present work was to transform the lectures sessions into practical classes. The student worked in the classroom looking for the information of the subject contents while they asked questions and shared the results with their classmates. The students worked in pairs for an active and collaborative learning. These work structures enhanced participation, autonomous learning and critical assessment of students.

In order to make decisions by the students in particular situations regarding with constructive systems, it is necessary to emphasize that they have to acquire a basic knowledge as well as specific competences of subjects taught in the first and second year of the Degree. The student must learn to choose the correct information from the Internet and they must distinguish whether or not it is updated and whether or not it is reliable. Therefore it is considered useful to carry out the courses offered by the General Library in the University of Alicante.

After the implementation of this work scheme, students were motivated to attend classes and to work collaboratively, increasing their academic performance compared to other years.

This new methodology, more constructive and practical, required more didactic materials made by the professor. The feedback between the students and between the students and the teacher was achieved through the analysis of the results obtained with the questionnaires made with the Socrative app. Students expressed a positive attitude towards the use of new technologies.

Taking advantage of this situation, it is necessary to continue working and thinking about new dynamic strategies that encourage communication, reflection, teamwork, collaboration and decision making, in situations related with the process of building execution, Figure 7.

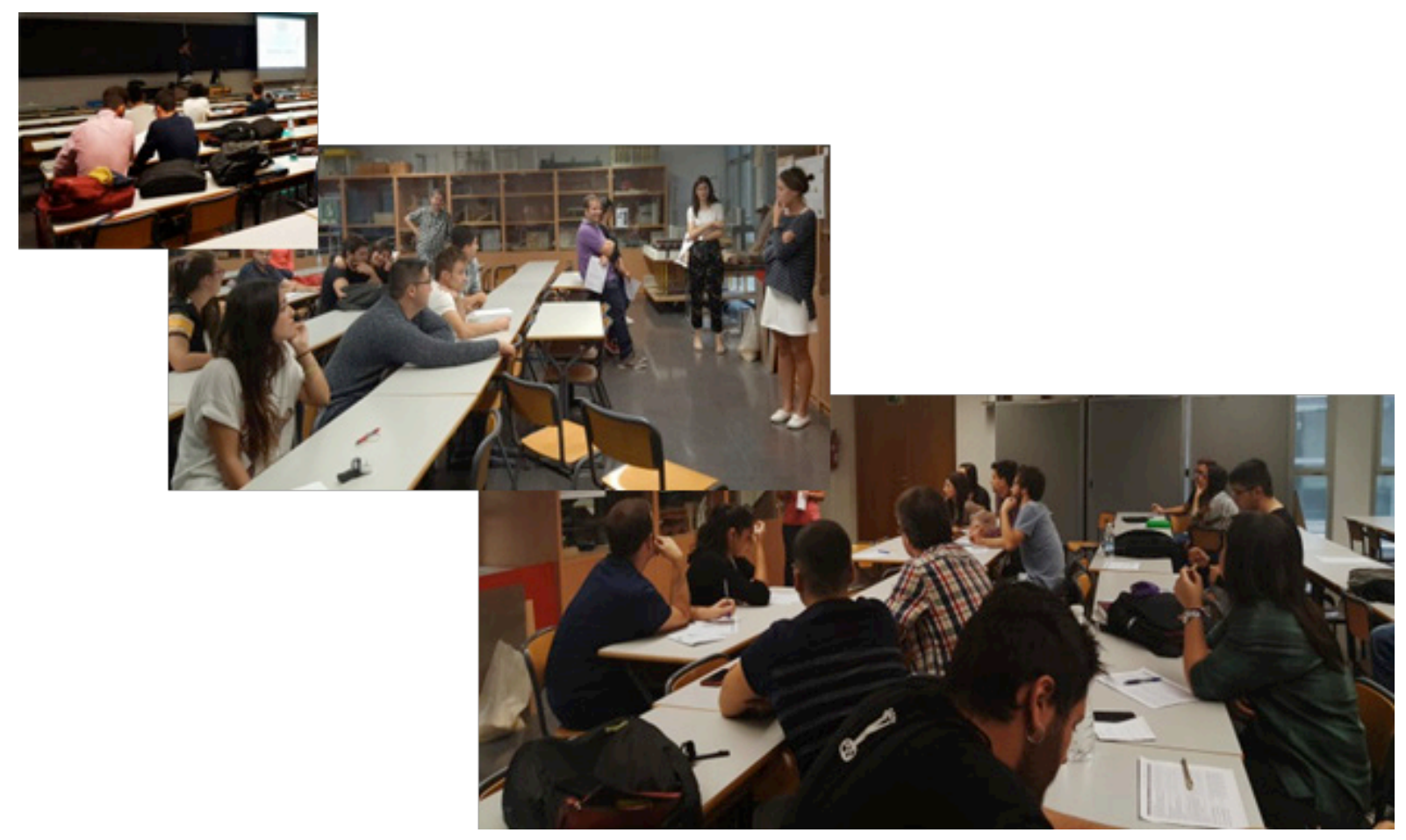

Figure 7. Collaborative workshops and posters exhibitions.

\section{REFERENCES}

[1] J. Beltrán Llera, "Estrategias de aprendizaje", Revista De Educación, (332), 55-73, 2003.

[2] S. G. Cabezas, and C. Alonso Granado, "Gamificación en entornos educativos universitarios". Comunicación y Pedagogía: Nuevas Tecnologías y Recursos Didácticos, (281), 86-91, 2015. 
[3] G. Castilla Cebrián, M. G. Romana, and B. López-Terradas Aparicio, "Concursando en el aula: la gamificación mediante quiz-show como herramienta de dinamización docente", 2013. Proceedings of $X$ Jornadas Internacionales de Innovación Universitaria. Educar para transformar. Universidad Europea, Madrid, 11-12 July, pp. 1527-1535, 2013.

[4] D. Alemany Martínez, "Estrategias de motivación en la adquisición de competencias informacionales en la enseñanza superior”, 2015. Available in: http://hdl.handle.net/10045/49630

[5] J. M. Muñoz, "NNTT, TIC, NTIC, TAC... en educación ¿pero esto qué es?”, 2008. Quaderns digitals: Revista de Nuevas Tecnologías y Sociedad, 51, pp. 43-60. Available in: http://www.quadernsdigitals.net/datos_web/hemeroteca/r_1/nr_773/a_10430/10430.pdf

[6] E. García González, M. D. Andújar Montoya, M. A. López Peral, A. García-Quismondo Cartes, R. Sánchez Valcárcel, A. Jiménez Delgado, E. Barba Casanovas and R. Pérez del Hoyo, "Aplicación de estrategias dinámicas en la enseñanza de Equipos de obra y maquinaria". Investigación e Innovación Educativa en Docencia Universitaria. Retos, Propuestas y Acciones", 2016, p.p.2844-2858. Available in: http://hdl.handle.net/10045/59668

[7] N. Carpena, M. Cataldi and G. Muñiz, "En busca de nuevas metodologías y herramientas aplicables a la educación". Repensando nuestro rol docente en las aulas, Vol. 3, p. 2015, 2012 [In search of new methodologies and tools applicable to education. Rethinking our teaching role in the classroom]. Proceedings of the 16th Iberoamerican Congress of Digital Graphics. Available in: http://cumincades. scix. net/data/works/att/sigradi2012_85

[8] A. Olaizola, "La clase invertida: usar las TIC para" dar vuelta" a la clase". Actas de las X Jornadas de Material Didáctico y Experiencias Innovadoras en Educación Superior, pp. 1-10, 2014.

[9] M.R. Sánchez, "Metodologías docentes en el EEES: De la clase magistral al portafolio". Tendencias Pedagógicas, pp. 83-102, 2015. 